\title{
The Problematic and Urgency About Scientific Research of Knowledge Development in Indonesia
}

\author{
Dimas Agung Trisliatanto ${ }^{1}$, Cholichul $\mathrm{Hadi}^{2}$, Sri Iswati ${ }^{3}$, Falih Suaedi ${ }^{4}$, Andre Fahreza ${ }^{5}$ \\ \{dimas.agung.trisliatanto-2018@pasca.unair.ac.id ${ }^{1}$, cholicul.hadi@psikologi.unair.ac.id ${ }^{2}$, \\ iswati@feb.unair.ac.id ${ }^{3}$, falih.suaedi@fisip.unair.ac.id ${ }^{4}$, andre.fahreza-2017@fisip.unair.ac.id $\left.{ }^{5}\right\}$
}

\begin{abstract}
Doctor Program Study of Human Resource Development, Postgraduate School of Universitas Airlangga, Jl. Airlangga No. 4-6, Surabaya, Indonesia ${ }^{1}$, Faculty of Psychology, Universitas Airlangga, Jl. Airlangga, Surabaya, Indonesia ${ }^{2}$, Islamic Economy Science, Faculty of Economy and Business, Universitas Airlangga, Jl. Airlangga No. 4, Surabaya, Indonesia ${ }^{3}$, Public Administration Department, Faculty of Social Science and Political Science, Universitas Airlangga, Jl. Dharmawangsa Dalam, Surabaya, Indonesia ${ }^{4}$, Bachelor Study Program of Library and Information Science. Faculty of Social Science and Political Science. Universitas Airlangga. Campus B. Jl. Dharmawangsa Dalam, Surabaya ${ }^{5}$
\end{abstract}

\begin{abstract}
Based on SCImago data, throughout 1996-2016, the number of global indexed publications in Indonesia reached 54.146 publications. When compared to Singapore, Thailand and Malaysia, Indonesia's ranking was still far below the three ASEAN countries. In 2016, at the world level, Indonesia was ranked 45th for the number of internationally published documents. The purpose of this paper was to identifying the factors that became a problem of research and the urgency of research scientists in the development of the world of science in Indonesia. This study used literature study with a conceptual approach. The results of this study explained that Indonesia had not been able to balance the rapid transformation of science and technology in the international world with quality research results, so that even though Indonesia had natural resources and potential human resources, Indonesia had not been able to produce enough research products.
\end{abstract}

Keywords: Science, Research, Scientific Research, Knowledge, Knowledge Development

\section{Introduction}

Indonesia's deterioration in the development of science and technology could be seen from parameters such as research and development (R\&D) funds which were ranked 42 of the 46 countries surveyed by IMD, thinked tank based in Switzerland. Under Thailand and Malaysia but still above the Philippines. But judging from the size of the per capita fund, Indonesia was only at the level above Venezuela which was at the bottom. More worrying was the interest of the younger generation in science and technology. Indonesia's position was far behind with neighbor countries trying to advance like Singapore $\left(1^{\text {st }}\right)$, Malaysia $\left(14^{\text {th }}\right)$, Philippine $\left(29^{\text {th }}\right)$ and Indonesia $\left(39^{\text {th }}\right)$. One of the causes, the lacked of international scientific publications which had an indicator of the low quality of research in Indonesia was the limited access of our researchers to international journals. The cost of subscribing to a journal in a year was quite expensive for a researcher. Especially to be optimal, a researcher must subscribe to more than one journal because in a particular discipline, there were usually several scientific journals that recognized as international references.

Indonesia's low ranking in science and engineering were related to the low national investment in the field of research and development closely. Indonesia, with a population of more than 230 million, which was the fourth largest country in the world by population. Illiteracy rates were very low and the country had several good universities and research institutions. Unfortunately, during 1996-2010, Indonesia was ranked $64^{\text {th }}$ in the world in the number of scientific articles published in journals that had gone through a peer assessment process. In addition, around $74 \%$ of science projects in Indonesia were international 
collaborations, so they must share their recognition with other countries. Although patents were more related to productivity in industry closely, many companies in various sectors did not apply for patents (or publish scientific articles) for business reasons [1].

However, the low level of private sector was spending on research and development may be an important factor in the low number of patents granted to Indonesia. Research and Development $(\mathrm{R} \& \mathrm{D})$ activities were actually carried out in many institutions in Indonesia, with more than $80 \%$ of the budget coming from the government. Most researchers and engineers worked in government scientific institutions, and they received the largest share of the country's R\&D budget. However, almost all researchers at the doctoral level work at state universities. Of all countries in the Southeast Asia region, apart from Vietnam which was a communist country, the contribution of the private sector to research in Indonesia was among the lowest and the contribution of the university was also very small.

This could be seen in the low output of $R \& D$ institutions in Indonesia about international publications. Based on SCImago data, throughout 1996-2016, the number of global indexed publications in Indonesia reached 54.146 publications. When compared to Singapore, Thailand and Malaysia, Indonesia's ranking was still far below the three ASEAN countries. In 2016, at the world level, Indonesia was ranked of $45^{\text {th }}$ for the number of published documents internationally. In the Asian region, Indonesia's position was ranked of $11^{\text {th }}$, while at the ASEAN level It ranked of $4^{\text {th }}$. In addition, the trend in the number of publication documents in Singapore, Thailand, Malaysia and Indonesia continued to increase. Starting in 2010, Malaysia shifted Singapore's position to $2^{\text {nd }}$ place. Regarding the published documents in Indonesia, the number increased to $46,41 \%$ (11.470 publications) compared to 7.834 publications in 2015 . Despite the increase, this figure was still far compared to Singapore (19.992 publications) and Malaysia (28.546 publications). Looked at Figure 1 below:

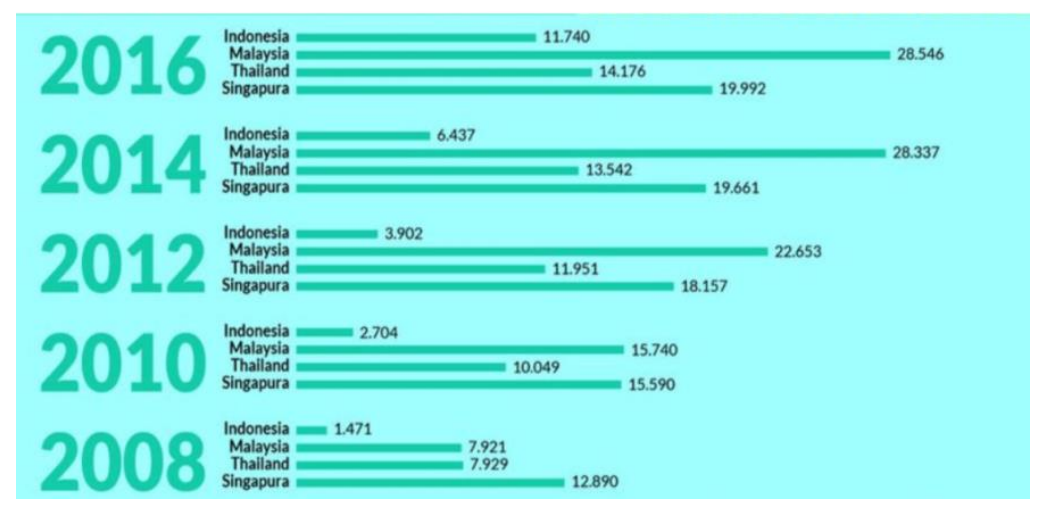

Fig. 1. Comparation of International Publication between Indonesia and Some Countries of ASEAN (Source: SCImago, 2016) 
Interestingly, the number of citation experienced a downward trend since 2013. In addition, although Malaysia was ranked of $1^{\text {st }}$ about published documents, when viewed from the number of citation, Malaysia was ranked of $2^{\text {nd }}$ (19.024 citations) after Singapore (32.504 citations) in 2016. Thailand ranked of $3^{\text {rd }}$ (11.331 citations) and Indonesia ranked of $4^{\text {th }}(4.604$ citations). In addition to publications, another way to saw research positions and contributions were the number of patents produced. Sourced from the United States Patent and Trademark Office, up to 2015, the total Indonesian patents registered with the US Patent Office total 333. This number was still very far compared to other ASEAN countries, such as Singapore (10.044 patents), Malaysia (2.690 patents), and Thailand (1.043 patents). Not only lagging, the grew of Indonesian patents but also showed a stagnant trend since 2005 . This could be seen in the following figure 2 :

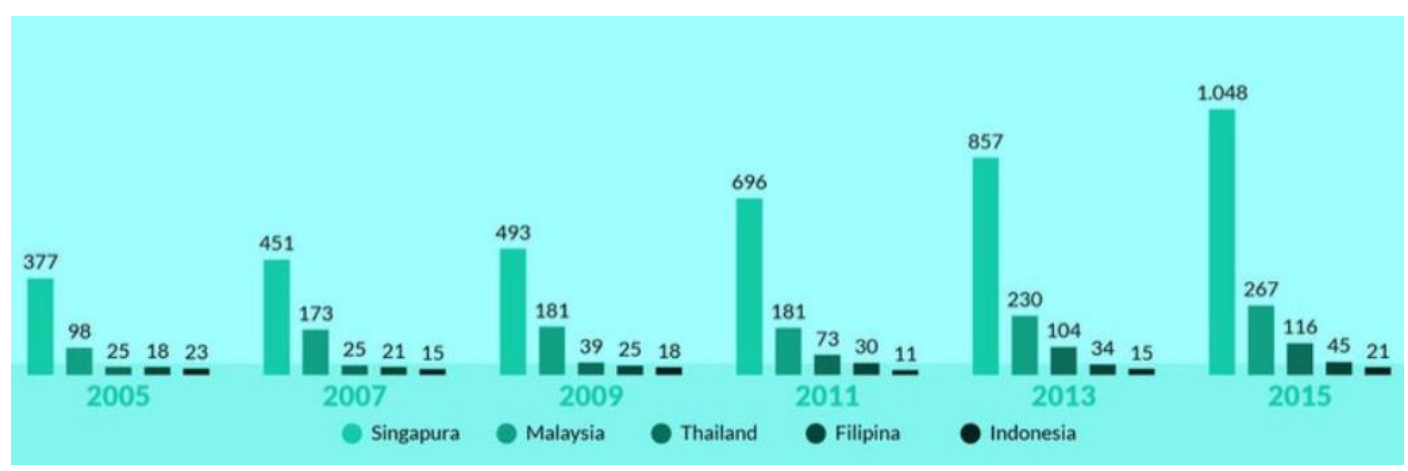

Fig. 2. Comparation of Patent between Indonesia and Some Countries of ASEAN Totally (Source: USPTO, 2016)

The low number of documents published internationally, one of them was due to the small number of researchers in Indonesia. Data from the Indonesian Institute of Sciences (LIPI) in 2017 showed researchers in Indonesia (only) amounting to 9.685 people. This figure was the number of researchers in all researchers functional officials from all Ministries in Indonesia. Indeed, there was a trend of increasing quantity since 2010. In 2010 the number of researchers in Indonesia reached 7.502 people, in 2012 there were 8.075 people. Figures continued to increasing about 9.128 people in 2014. This was due to one of them because these institutions did not have access to the latest information on the development of research and development of science and technology from international sources, due to limited funds allocated by the government. As a result the researchers did not have the opportunity to gained the latest access to the development of science and technology, through international journals in their fields. This was results in the quality of research conducted by researchers in research and development institutions that could not be increased or even worsen and they were unable to make publications that suitable for publication in international journals consequently.

The Ministry of Research, Technology, and Higher Education as the ministry that coordinated research activities in Indonesia, must answered this problem. One of the things that could be done was to collecting subscriptions to international scientific journals and managing an online library network system so that international scientific journals could be accessed by researchers from their respective laboratories collectively. Bador and Lafouge stated that a country had greater potential to be able to market Its findings if It had a scientific community that widely publishes publications in various fields and produced innovations that 
deserve a patent [2]. Almost all scientists in Indonesia agreed that this country had not been able to produce as much patent knowledge or innovation as expected. This was supported by evidence of the limited number of publications and patents produced by Indonesia. Comparative data generated from international sources stated that every dollar invested in Indonesia did not show results that were equivalent to the achievements of researchers in other countries.

Indonesia's productivity in the field of science and technology was not also comparable with other countries that were vast and the amount of resources such as Indonesia. Scientists believe this was due to the difficulty of seeking support to finance research projects and inflexible financial reporting and reporting systems. Another obstacle that was rarely mentioned that the heavy burden of teaching at the university and the offered of higher salaries for a career in non-science of Non-Ministry Government Institutions of Indonesia. Though, these two things were made scientists reluctanted to do research. Indonesia did not have the financial infrastructure to supported innovative science and technology. The country also did not have the infrastructure to allocated and chained the channel funds to researchers, provided research facilities, and flexibled budgeting systems to conducted scientific research. In addition to these issues, there were bigger problems, namely the low national investment in research and development. Indonesia's gross investment in research and development was less than $0,1 \%$ of GDP, almost too low to be able to appeared in published report charts.

All of these problems could be handled at once in a system through the establishment of the Indonesian Science Fund, an independent body that on the basis of competition could provided funds to scientists and engineers to conducted world-class research directly. One of the conditions for granting funds was the existence of institutional supported for researchers to increase productivity. Instead, this agency would provided compensation for the costs incurred by the agency. Many countries had recognized that the establishment of a national fund body that provided competitive grants was the most effective way to support world-class engineering science and science. The selection processed and extensioned of grants based on results such as publications and patents encouraged the value of scientific productivity. Given that scientific publications were selected by the best international journals to be published competitively, researchers must had an extensive network throughout the world if they wanted to make their research efforts leading.

Scientists who wanted to participate in research projects funded by donor agencies must collaborated with overseas colleagues. These colleagues from other countries would received grants and replace all Indonesian partners' expenses. This scheme could not be the basis of equal cooperation. The low number of scientific publications did not reflect the number of scientists and engineers in Indonesia necessarily, nor the level of investment in science and technology. A number of countries were smaller than Indonesia, with far fewer scientists and engineers, in fact able to outperformed Indonesia in producing research compared to the amount of money invested. The problems were more systemic and related to the allocation of resources including human resources and the research environment which was likely not to provided freedom and autonomy that conducived to promoting innovation. Career paths for scientists were too rigid and limit opportunities for researchers.

But the risks and sanctions in the career level were also small so they did not spur researchers to be more productive. Career advancement in the field of science in universities and other institutions should be based on the quality of results and contributions to knowledge or technology. A competitive funding source such as the Indonesian Science Fund which had given based on excellence, ideas originality, and ability, would provided incentives and rewards that were good for achieving these goals. Many program models had succeeded in 
training and supporting entrepreneurs and encouraging entrepreneurship. Some of the most successful programs were those based on universities, where they helped students and lecturers to developed and sold the results of their research, sometimes for the benefit of the university Itself. The purpose of this study were following: 1.) To described the problematic and urgency about scientists research of knowledge development in Indonesia to find problem solving; 2.) To identified the factors of problematic and urgency about scientists research of knowledge development in Indonesia.

\section{Literatures}

\subsection{Research}

Etymologically, research meant "searching back" for new facts which were then developed into a theory to deepened and expanded certain knowledge. Every scientist both exact and non-exact were carrying out research must be based on curiosity. Curiosity could lead to their desire to conducted research to deepened and expanded the knowledge they pursued. Karlsson, et. al. stated that research was a scientific activity based on analysis and construction that was carried out systematically, methodologically and consistently and aimed to reveal the truth as a manifestation of human desire to knew what It was facing [3]. Ary, Jacobs, and Razavieh said that research was the application of a scientific approached to an assessment of problems in obtaining useful information and result that could be accounted for [4].

Research was the fact finding according to a cleared objective method in finding the relationship between facts and producing certain laws [5]. Morgan revealed that research was a search for everything that was done systematically, with the emphasis that the search was carried out on problems that can be solved by research [6]. Gozali, et. al. revealed that research as an attempted to found, developed and tested the truth of a knowledge by using scientific methods [7]. Tous, Guerrero, and Delgado described that research as a process of collecting and analyzing or processing data that was carried out systematically and logically to achieved certain goals [8].

\subsection{Characteristic Identification of Research}

According to Hoyles, et. al., research had several characteristics and characteristics, among others, as follows: 1.) Passive, just wanted to got a picture of a situation or problem; 2.) Active, wanted to solved a problem or tested a hypothesis [9]. His own research position in general was to linking among others: human desires, problems that arise, science, and scientific methods. The characteristics of scientific research were following: 1.) Purposiveness; 2.) Rigorous; 3.) Testibility; 4.) Replicability; 5.) Objectivity; 6.) Generalizability; 7.) Precision; 8.) Parsimony [3].

Research conducted by scientific methods was called scientific research. A study must fulfilled several characteristics to be said to be scientific research. Generally there were five characteristics of scientific research, among others: 1.) Systematic (a study must be arranged and carried out sequentially according to the correct pattern and rules, from easy and simple to complex); 2.) Logical (a study was said to be true if It was acceptable to reason and based on empirical facts); 3.) Empirical (a study was usually based on everyday experience; 4.) 
Objective (a study of subjective aspects that did not mix It with ethical values); 5.) Replicative (a study that had been carried out must be retested by other researchers and must provided the same results when done with the same method, criteria and conditions) [4].

\subsection{Scientific Research Method}

Research could be classified in two, in accordanced with the quality measures, namely scientific research and unscientific research or carried out by ordinary people [4]. Unscientific research had characteristics that were not systematic, data collected and methods of collecting data were subjective which were loaded with emotional and feelings of the researcher. Therefore, unscientific research was a subjective research. While scientific research was a systematic and objective activity to examined a problem in an effort to achieved an understanding of Its fundamental principles and applied (theory) about the problem generally [3]. Research conducted, according to Hoyles et.al. were guided by various information (manifested as theories) that had been produced in previous studies, and the aim was to added or refined existing theories about the problems being subjected to study [9]. Unlike scientific research, scientific research was carried out based on scientific methods.

The scientific method was a basic framework for the creation of scientific knowledge. In science was done by using methods of observation, experimentation, generalization, and verification. Whereas in the social and cultural sciences, the most was done using interview and observation methods; experiments, generalizations, and verification were also carried out in research activities by experts in the fields of social sciences and cultural knowledge to obtain certain research results in accordance with the objectives of the research [6]. The scientific method was based on the idea that knowledge was realized through what was experienced by the senses, especially through observation and hearing. So that if a statement regarding the symptoms must be accepted as truth, then the symptoms must be verified empirically. So, every law or formula or scientific theory must be made based on the existence of empirical evidence.

\subsection{The Role of Research Journal Publications}

Scientific journals were considered as the primary or most important source of information in the world of science and technology. Scientific journals contained a collection of articles that were published periodically, written by research scientists to report the results of their latest research [10]. Because of this, the existence of scientific journals was important to continued and advanced science and technology. Articles published in scientific journals had undergone a rigorous peer-review and selection processed from experts in their respectived fields. This peer-review processed was carried out to guaranteed the quality and scientific validity of the articles that were published. Publication of research results was an important part of scientific methods. Writing in scientific journals was intended for researchers and other experts in the same field [9].

Articles in a journal must be so cleared that an independent researcher could repeated the experiment or calculation to verify the results of his research. Articles in journals would be part of a permanent scientific record. Scientific journals had 3 roles in the scientific communication process, such as: 1.) Social role, to built and maintained intellectual property, so that a creative and innovative worked of a scientist would got recognition from the world of related scientific disciplines; 2.) The role of the archived, to provided scientific recognition that the published article had been evaluated and declared acceptable to the world of science; 
3.) The role of information dissemination was very essential because of the cumulative nature of science (to grew continually) [11].

\section{Method}

This study used literature study with a conceptual approach. Literature study was a data collection technique by conducting of books, literatures, notes, and reports that had to done with the problem became solved [12]. A conceptual approach was an approach that moved on the concepts that developed in information sciences and libraries that were often used [3].

\section{Result and Discussion}

In many countries that had experienced advances in science and technology, scientific journals published in international journals were one important measure to measure the quality of research. In some developed countries such as Japan, England and America, the number and quality of published scientific journals were even used as a measure to determine how much research funding would be given to the laboratory. Scientific journals were considered representative of the assessment of the quality of research sufficiently, considered that the journal would be tested by researchers who were competent in their fields before being declared eligible for publication in the scientific journal [2]. Analysis from the National Science Foundation (NSF), a prestigious science institution belonging to the American government, stated that the number of scientific journals produced by the United States intended to remain year after year in the last decade, while other countries had increased. NSF stated that China, South Korea, Singapore and Taiwan had the highest growth among other Asian countries, besides Japan which had a strong tradition of publishing scientific journals. Indonesia had not been able to balance the rapid transformation of science and technology in the international world with quality research results, so that even though Indonesia's country had natural resources and potential human resources, Indonesia had not been able to produce enough research products. On the other hand allowances and facilities to conducted research were also inadequate, even though quality research products were produced from the quality of intellectual processes. Research publications could be used as an illustration of research culture in Indonesia. Research was the first gate to the contribution of science to the progress of the nation [13]. The condition of domestic research assessed from the Scopus index showed that research publications in Indonesia were still far behind compared to countries in Southeast Asia. The data of 2014 from Scimago showed that Indonesia's position was disappointing compared to other Asian countries [14].

The data description in Scimago showed that Indonesia had 113 articles indexed in Scopus, with H-index of 16, so It ranked of 11th under the Philippines which had 114 articles with Hindex of 17th, It ranked of 10th. While Thailand had 290 articles, with H-index of 18, It ranked of 9th. We were still far behind Malaysia, which had 854 articles indexed in Scopus, with H-index of 19, It ranked of 8th. The 7th place was occupied by India with 1.559 articles and $\mathrm{H}$-index of 36. The 6th place was occupied by Singapore with 1.152 articles, with H-index of 40. In the 1st place, Japan ranked the top five (7.496 articles with H-index of 74), the 2nd place is Hong Kong (2.504 articles with H-index of 70), the 3rd place is China (2.760 articles with $\mathrm{H}$-index of 53), the 4th place is Taiwan (2.494 articles with $\mathrm{H}$-index of 53), and the 5th is 
South Korea (1.715 articles with H-index of 50). In 2014, the data from Scimago showed that Indonesia still lags far below Malaysia as a allied country. Indonesian compared to Malaysia, not only in research publications, but also in terms of the amount of research funding to supported research in universities [15].

Almost all scientists in Indonesia agreed that this country had not been able to produce as much knowledge or innovation as expected. This data was evidence of the lack of publications and patents produced by Indonesia. Comparative data generated from international sources stated that every dollar invested in Indonesia did not show results that were equivalent to the achievements of researchers in other countries [5]. Indonesia's productivity in the field of science and technology was also not comparable with other countries that were vast and the amount of resources such as Indonesia [16]. Scientists believe this was due to the difficulty of seeking supported to financed research projects and inflexible financial reporting and reporting systems [17]. Another obstacle that was mentioned the heavy burden of teaching at the university and the offer of higher salaries for a career in non-science in Non-Ministry Government Institutions rarely. Though these two things were what made scientists reluctanted to did research. Indonesia did not have the financial infrastructure to supported innovative science and technology. The country also did not have the infrastructure to allocated and chained the channel funds to researchers, provided research facilities, and flexibled budgeting systems to conducted scientific research. In addition to these issues, there were bigger problems, namely the low national investment in research and development.

In addition to passion in conducting research, the problem in terms of funding must be solved and improved so that It could be handled at once in a system through the establishment of the Indonesian Science Fund, an independent body that on the basis of competition could provided funds to scientists and engineers to conduct world-class research directly. One of the conditions for granting funds was the existence of institutional supported for researchers to increased productivity. Instead, this agency would provided compensation for the costs incurred by the agency. In Indonesia, there were not many relationships built between science institutions and universities and the private sector includes science-based small and mediumsized companies which were centers of innovation in many countries.

According to the data, only a few scientists worked in the private sector, while investment in technical innovation was also small. The small size of the company, the lack of clarity about what was included in the research, and the limited relationship between government research institutions and private companies were often referred to as obstacles in adopting technology [6]. Most non-extractive industries were based on imported products, which had little added value. For this reason, additional policy incentives were needed to encouraged value and innovation. At the same time, the current government financing mechanism offered very little incentive for government $\mathrm{R} \& \mathrm{D}$ institutions to collaborated with the private sector. For example, the latest fiscal law stated that all government agencies must be funded by the Government State Budget fully.

The allocation of Government State Budget was also considered adequate to conducted all research activities. This meant that all $R \& D$ funds from the private sector and external sources to state institutions or universities must be provided through the Ministry of Finance. The fund would be non-tax state revenue and could only be taken through the budget line in the process of budgeting the annual State Budget. Scientists who wanted to participate in research projects funded by donor agencies must collaborated with overseas colleagues. These colleagues from other countries would received grants and replaced all Indonesian partners' expenses. This scheme could not be the basis of equal cooperation. 
The low number of scientific publications did not reflect the number of scientists and engineers in Indonesia, nor the level of investment in science and technology necessarily. A number of countries were smaller than Indonesia, with far fewer scientists and engineers, in fact able to outperformed Indonesia in producing research compared to the amount of money invested. The problems were more systemic and related to the allocation of resources including human resources and the research environment which were not to provided freedom and autonomy that wass conducived to encouraging innovation likely [18]. Career paths for scientists were too rigid and limit opportunities for researchers.

But the risks and sanctions in the career level were also small so they did not spur researchers to be more productive. Should, career advancement in the field of science in universities and other institutions based on the quality of results and contributions to knowledge or technology. A competitive funding source such as the Indonesian Science Fund which was given based on excellence, originality of ideas, and ability, would provided incentives and rewards that were good for achieving these goals. Grants could be given to universities to created incubators to served the academic community and other parties.

\section{Conclusion}

For Indonesia, the contribution of domestic scientists in fact was quite alarming. From the funding problem which was only $0,9 \%$ of the state budget until the licensing problem becames a big obstacle in optimizing research by scientists [17]. This caused Indonesian scientists to choose to went abroad and join leading universities, research institutions, or research institutions in the country to developed their potential in the scientific field. Eventhough, Indonesia had human resources in the scientific field that were quite capable. But the lacked of synergy between the government and educational and industrial institutions seems to turned them off. It would be a wise move if Indonesia optimized research conducted by domestic scientists, giving them a place to conducted scientific research.

Of course this would benefited the human life in Indonesia later. Indonesia could started by circulating the capabilities of innovation, intelligence, research and technology, and improving the quality of human resources. In addition, It was also very important to built intensive communication and networks by the government, industry, and academic institutions with relevant institutions abroad [18]. Then Indonesia built communication with Indonesian human resources in overseas research institutions to contributed actively and cooperated in developing technology in the country. Of course, It also provided opportunities for scientists and related human resources to be involved with research projects directly. Equally important, the government also did not forget to give awards to scientists for their worked in their respective scientific fields.

Acknowledgments. The authors said thank you to the lecturers of the Philosophy and Logical Science major who had guided the making of this journal up to the completion stage and colleagues who helped in sharing information and data related to this journal writing. 


\section{References}

[1] Davidson, J. \& Jacobs, C.: The implications of qualitative research software for doctoral work. Vol. 8 (2), pp. 72-80. Qualitative Research Journal (2008). DOI:10.3316/QRJ0802072

[2] Bador, P. \& Lafouge, T.: Comparative analysis between impact factor and h-index for Psychiatry Journals. Vol. 35 (2), pp. 109-121. Analyse Comparative du Facteur d'Impact et de I'Indice h dans les Revues de Psychiatrie (2011)

[3] Karlsson, J. Marx, R. G. Nakamura, N. \& Bhandari, M.: A practical guide to research: Design, execution, and publication. Vol. 21 (4), pp. 1-10. The Journal of Arthroscopic and Related Surgery (2011). DOI:10.1016/j.arthro.2011.02.001

[4] Ary, D., Jacobs, L. C. \& Razavieh, A.: Introduction to research in education 8th edition, Wardswoth Cengange Learning. Nelson Education ltd, Canada (2010)

[5] Rakhmani, I. \& Siregar, F.: Reforming research in Indonesia: Policies and practice. Vol. 92, pp: 1-44. Global Development Network (2016)

[6] Morgan, F.: The diverification between scientific research and social research. EGC, Jakarta (2009)

[7] Gozali, L. et. al.: Research gap of entrepreunership, innovation, economic development, business incubators studies in Indonesia. Vol. 7 (2), pp. 243-248. International Journal of Economic and Financial Issues (2017)

[8] Tous, R. Guerrero, M. \& Delgado, J.: Semantic web for reliable citation analysis in scholarly publishing. Vol. 30 (1), pp. 24-31. Information Technology and Libraries (2011)

[9] Hoyles, C. Kuchemann, D. Healy, L. \& Yang, M.: Student's developing knowledge in a subject discipline: insight from combining quantitative and qualitative methods. Vol. 8 (3), pp. 225-238. International Journal of Social Research Methodology (2005). DOI:10.1080/13645570500154899

[10] Garfield, E.: The history and meaning of the journal impact factor. Vol. 295 (1), pp. 9093. Journal of The American Medical Association (2006). DOI:10.1001/jama.295.1.90 PMID:16391221

[11] Creswell W. J.: Research design of qualitatif, quantitative, and mixed. Yogyakarta: Pustaka Pelajar (2016)

[12] Daniel, B. K.: Handbook of research on methods and techniques for studying virtual communities: Paradigms and phenomena (Vol. 1). USA: IGI Global-Imprint Science Reference (2011)

[13] Hwang, G. J. \& Tsai, C. C.: Research trends in mobile and ubiquitos learning: a review of publications in selected journals from 2001 to 2010. Vol. 42 (4), pp. 65-70. British Journal of Educational Technology (2011). DOI:10.1111/j.1467-8535.2011.01183.x

[14] SCImago.: Scientific Journal Ranking (2014). Accessed by: www.scimagojr.com

[15] SCImago.: Scientific Journal Ranking (2016). Accessed by: www.scimagojr.com

[16] Payumo, J. et. al.: An entrepreneurial, research-based university model focused on intellectual property management for economic development in emerging economies: The case of Agricultural University, Indonesia. Vol. 36, pp. 22-31. World Patent Information (2014)

[17] Ministry of Research, Technology, and High Education.: Perencanaan sistem informasi jurnal karya bangsa, Jakarta (2011)

[18] Wang, V. C. X.: Handbook of research on scholarly publishing and research methods. IGI Global-Imprint Science Reference, USA (2015) 
[19] Wen, B. Ying, C. H. \& Chu, C. W.: University-Industry research collaboration in Taiwan. Vol. 33 (6), pp. 665-683. Journal of Information and Optimization Science (2012) 